\title{
PENGEMBANGAN LEMBAR KERJA SISWA (LKS) BAHASA INDONESIA KELAS VII DENGAN MODEL PEMBELAJARAN BERBASIS MASALAH
}

\author{
Sri Rahayu \\ Alumni Program Pascasarjana \\ Universitas Islam Darul Ulum Lamongan
}

\begin{abstract}
Abstrak:Tujuan penelitian ini adalah (1) memaparkan proses pengembangan Lembar Kerja Siswa (LKS) Bahasa Indonesia Kelas VII dengan model pembelajaran berbasis masalah, (2) Memaparkan kualitas Lembar Kerja Siswa (LKS) Bahasa Indonesia Kelas VII dengan model pembelajaran berbasis masalah yang dikembangkan, meliputi : (a) kualitas produk Kerja Siswa (LKS), dan (b) kualitas penggunaan Lembar Kerja Siswa $(L K S)$. Jenis penelitian ini adalah peneltian pengembangan denganmodel 4-D adalah define, (pendefinisian), design (desain dan perancangan), develop (pengembangan), dan disseminate (diseminasi atau penyebaran). Pengumpulan data dilakukan dengan instrmen lembar validasi ahli, lembar keusioner, lembar observasi. Teknik analisa data dalam penelitian ini dibagi menjadi tiga yaitu, teknik analisis data kualitas LKS dan penerapan LKS dengan model pembelajaran berbasis masalah.Hasil penelitian menunjukkan bahwa proses pengembangan terdiri dari dua tahap:(1)tahap analisis pemahaman penyusun tentang LKS dan kebutuhan siswa dan (2) tahap perancangan antara lain menghasilkan rangkuman materi tiap-tiap kompetensi dasar. Kualitas produk berdasarkan validasi ahli diperoleh rata-rata $72,48 \%$ berarti baik, kualitas penggunaan berdasarkan kuesioner kepada guru dan observasi terhadap siswa diperoleh rata-rata 75,65\% berarti baik.
\end{abstract}

Kata kunci: pengembangan, lembar kerja siswa, pembelajaran berbasis masalah

Abstract:The research aimed to (1) describe the process of developing the Indonesian Student Workheet using Problem Based Learning Model, (2) show the quality of the Indonesian Student Work Sheet using Problem Based Learning Model, including: (a) the product quality of the Student Worksheet and $(b)$ the using quality of the Student Worksheet. The type of the research was research and development using 4-D model, those are definition, design, development, and dissemination. The data collection used instrument of validation sheet from the expert, questionnaire sheet, observation sheet. The technique of data analysis divided into three, the technique of data analysis of student worksheet quality and the implementation of student work sheet using Problem Based Learning. The results showed that the development process consisted of two stages: (1) the analysis phase of the writer's understanding about the Student Worksheet and it's need, and (2) the design phase which produced the summaries of the materials in each basic competences. The product quality based on the expert gained the score in average of $72.48 \%$, good, the using quality based on the questionnaires to the teacher and observation to the students gained the score in average of 75, 65, good.

Keywords: development, student worksheets, problem-based learning 


\section{PENDAHULUAN}

Bahan ajar dapat dikelompokkan menjadi empat yaitu : (1) Bahan cetak (printed) antara lain handout, buku, modul, lembar kerja siswa, brosur, leaflet, wallchart, foto/gambar, model/maket. (2) Bahan ajar dengar (audio) seperti kaset, radio, piringan hitam, dan compact disk audio. (3) Bahan ajar pandang dengar (audio visual) seperti video compact disk, film. (4) Bahan ajar interaktif (interactive teaching material) seperti compact disk interaktif (Abdul Madjid, 2007).

Masalah penting yang sering dihadapi guru dalam kegiatan pembelajaran adalah memilih atau menentukan materi pembelajaran atau bahan ajar yang tepat dalam rangka membantu siswa mencapai kompetensi. Hal ini disebabkan oleh kenyataan bahwa dalam kurikulum atau silabus, materi bahan ajar hanya dituliskan secara garis besar dalam bentuk

"materi pokok". Menjadi tugas guru untuk menjabarkan materi pokok tersebut sehingga menjadi bahan ajar yang lengkap. Selain itu, bagaimana cara memanfaatkan bahan ajar juga merupakan masalah. Pemanfaatan dimaksud adalah bagaimana cara mengajarkannya ditinjau dari pihak guru, dan cara mempelajarinya ditinjau dari pihak murid.

Salah satu bahan ajar yang sudah dikenal dan banyak dipergunakan dalam kegiatan belajar mengajar secara umum oleh lembaga sekolah adalah Lembar Kerja Siswa (LKS). Bagi guru fungsi LKS adalah untuk menentukan siswa dapat belajar maju sesuai dengan kecepatan masing-masing dan materi pelajaran dapat dirancang sedemikian rupa sehingga mampu memenuhi kebutuhan siswa, baik cepat maupun yang lambat membaca dan memahami (Azhar Arsyad, 2005).
Lembar Kerja Siswa (LKS), dalam pemanfaatannya biasanya diberikan kepada tiap siswa yang mana nantinya guru menugaskan siswa untuk mengerjakan berbagai soal yang terdapat di dalam LKS tersebut. Penggunaan LKS oleh guru sangat membantu guru dalam melaksanakan pembelajaran karena pada LKS ini terdapat soal-soal yang dapat langsung dikerjakan. Ketika guru telah selesai memberikan materi pelajaran kepada siswa, maka siswa dapat memantapkan materi tersebut dengan mengerjakan soal-soal latihan yang terdapat pada LKS. Namun dalam pemanfaatannya LKS ini kurang efektif karena sering tidak aktual, tidak menantang dalam penyelesaian, dan tidak menarik minat siswa untuk mengerjakannya, tetapi peserta didik dituntut harus tetap mengerjakan tanpa ada evaluasi soal-soal dari guru mata pelajaran yang bersangkutan.

Oleh karena siswa terkadang tidak memiliki masalah dalam pembelajaran tersebut, maka inisiatif harus dimunculkan agar siswa mempunyai masalah. Setelah siswa memiliki masalah, mereka digiring untuk berkeinginan menyelesaikan masalah tersebut melalui motode yang ditetapkan. Hal inilah salah satu cara pengembangan LKS dengan model pembelajaran berbasis ilmiah.

Uraian di atas memberi inisiatif kepada penulis untuk melakukan penelitian tentang Pengembangan Lembar Kerja Siswa (LKS) Bahasa Indonesia Kelas VII dengan Model Pembelajaran Berbasis Masalah.

Tujuan khusus penelitian ini sebagai berikut :

1) Memaparkan proses pengembangan Lembar Kerja Siswa (LKS) Bahasa Indonesia Kelas VII dengan model pembelajaran berbasis masalah. 
2) Memaparkan kualitas Lembar Kerja Siswa (LKS) Bahasa Indonesia Kelas VII dengan model pembelajaran berbasis masalah yang dikembangkan.

a. Memaparkan kualitas produk Lembar Kerja Siswa (LKS) Bahasa Indonesia Kelas VII dengan model pembelajaran berbasis masalah yang dikembangkan.

b. Memaparkan kualitas penggunaan Lembar Kerja Siswa (LKS) Bahasa Indonesia Kelas VII dengan model pembelajaran berbasis masalah yang dikembangkan.

\section{METODE PENELITIAN}

Penelitian ini merupakan jenis penelitian pengembangan. Subjek penelitian pengembangan ini adalah (1) Siswa Kelas VII E, VII F, VV G, dan VII H, SMP Negeri 1 Kebomas Kabupaten Gresik, (2) Guru Bahasa Indonesia Kelas VII E, VII F, VV G, dan VII H, SMP Negeri 1 Kebomas Kabupaten Gresik, dan(3) Validator ahli pembelajaran, validator ahli bahasa, dan validator ahli grafika.

Data dalam penelitian ini terdapat dua jenis, yaitu data primer dan data sekunder. Data primer diperoleh dari lembar wawancara, observasi, dan kuesioner. Sedangkan data sekunder diperoleh dari dokumen berupa LKS.

Instrumen pengumpulan data dalam penelitian ini adalah lembar validasi ahli, lembar observasi, lembar wawancara, dan kuesioner.

a. Lembar Validasi Ahli

b. Kuesioner/Angket

c. Lembar Observasi

Teknik pengumpulan data diawali dengan permintaan kepada validator (para ahli di bidangnya) untuk menilai LKS Bahasa Indonesia kelas VII dilihat dari tiga aspek yaitu bahasa, model pembelajaran berbasis masalah, dan grafika (tata letak). Hasil dari validasi ini merupakan nilai atau status LKS apakah LKS tersebut sudah memenuhi kriteria bahasa yang baik, memiliki model pembelajaran berbasis masalah, dan memiliki tata grafika yang baik atau belum. Selanjutnya pengumpulan data juga dilakukan untuk mengetahui penerapan LKS bagi siswa. Pengumpulan data ini dilakukan dengan observasi dengan instrumen lembar observasi yang telah disiapkan.

Teknik analisa data dalam penelitian ini dibagi menjadi tiga yaitu, teknik analisis data kualitas LKS dan penerapan LKS dengan model pembelajaran berbasis masalah. Di bawah ini dijelaskan teknik analisis data, untuk lembar validasi ahli, lembar kuesioner, dan lembar observasi.

\section{HASIL PENELITIAN \\ Proses Pengembangan LKS}

LKS yang dikembangkan oleh peneliti dalam penelitian pengembangan ini adalah LKS Bahasa Indonesia Kelas VII Semester Genap pada Kompetensi Dasar 9.1, Kompetensi Dasar 10.1, dan Kompetensi Dasar 11.3.

\section{Tahap Pendefinisian}

\section{Analisis Awal Pembuatan LKS}

Keberadaan buku ajar bukan satusatunya sarana pembelajaran bagi peserta didik saat ini, meskipun buku ajar berisi materi seperti yang ditetapkan dalam kurikulum, peserta didik juga memerlukan pegangan sumber belajar lainnya agar pembelajaran lebih hidup dan terarah.

Pada kenyataannya guru memiliki segudang tugas dan kewajiban yang sangat menyita waktunya, mulai dari mempersipkan pembelajaran, mengajar di kelas, mengevaluasi dan mengoreksi, sampai pada tugas administrasi yang masih dibebankan kepadanya. Hal inilah 
yang sering menjadi alasan ketidakberdayaan guru untuk mengembangkan diri dalam hal menyusun dan mengembangkan bahan ajar. Akhirnya, proses pembelajaran berlangsung dengan sumber belajar yang sudah tersedia, yaitu buku ajar dari berbagai penerbit yang ada.

Berkaitan dengan hal itu, maka sudah waktunya guru memiliki kemampuan tambahan selain mengajar, yaitu mengembangkan dan menyusun bahan ajar, khususnya yang berupa bahan ajar bentuk cetak. Dengan menyusun bahan ajar sendiri diharapkan lebih mengena, karena guru berhubungan langsung dengan mereka sehingga lebih memahami sifat dan karakter peserta didiknya. Oleh karena itu sangat penting bagi guru memperoleh pengetahuan tentang bagaimana mengembangkan dan menyusun bahan ajar bentuk cetak, mulai dari bentuk sederhana seperti handout, LKS sampai pada bentuk yang memerlukan pemikiran yang lebih lama dan mendalam, seperti diktat, modul, dan buku ajar.

\section{Analisis Kebutuhan Siswa}

Lembar Kerja Siswa (LKS) merupakan salah satu jenis alat bantu pembelajaran, bahkan ada yang menggolongkan dalam jenis alat peraga pembelajaran. Dalam pengertian lainnya Lembar kerja siswa (LKS) ialah lembar kerja yang berisi informasi dan perintah/instruksi dari guru kepada siswa untuk mengerjakan suatu kegiatan belajar dalam bentuk kerja, praktek, atau dalam bentuk penerapan hasil belajar untuk mencapai suatu tujuan.

Secara umum LKS
perangkat pembelajaran $\begin{array}{r}\text { sebagai } \\ \text { pelengkap atau sarana pendukung } \\ \text { pelaksanaan Rencana Pelaksanaan } \\ \text { Pembelajaran (RPP). Lembar kerja siswa } \\ \text { berupa lembaran kertas yang berupa }\end{array}$

informasi maupun soal-soal (pertanyaanpertanyaan) yang harus dijawab oleh peserta didik. LKS ini sangat baik digunakan untuk menggalakkan keterlibatan peserta didik dalam belajar baik dipergunakan dalam penerapan metode terbimbing maupun untuk memberikan latihan pengembangan.

\section{Analisis Cara Pemahaman Siswa terhadap KD}

Dalam proses belajar mengajar, guru membutuhkan alat sebagai pendukung atau penunjang dalam menyampaikan materi serta untuk mencapai tujuan yang diinginkan. Alat yang digunakan dapat berupa media dan bahan ajar.

Lembar kerja siswa berfungsi sebagai sarana untuk mengaktifkan siswa, merangsang belajar siswa untuk menyampaikan informasi agar memahami dan menghayati suatu konsep, melatih keberanian mengemukakan pendapat secara sistematis serta melatih siswa mengambil kesimpulan sendiri.

\section{Analisis Konsep LKS}

Saat ini di sekolah-sekolah banyak ditemui penggunaan buku jenis LKS (Lembar Kerja Siswa) yang sebenarnya merupakan buku rangkuman materi pelajaran yang disertai dengan kumpulan soal, terutama soal-soal pilihan ganda. LKS yang semestinya dikerjakan di sekolah dalam kegiatan pembelajaran, seringkali juga harus dikerjakan di rumah sebagai pekerjaan rumah (PR). Dalam LKS jenis ini, materi pelajaran biasanya tidak disampaikan dalam bentuk uraian/bacaan, melainkan sudah dalam bentuk rangkuman atau poin-poin penting saja. Akibatnya, ketika menggunakan LKS ini, siswa-siswa cenderung langsung mengerjakan soal-soal, yang pada umumnya berupa soal-soal pilihan ganda. Jika siswa tidak dapat mengerjakan 
sebuah soal, maka siswa akan mencari jawabannya dalam rangkuman materi pelajaran di LKS tersebut. Jika kondisi ini dibiarkan terus-menerus, bukan tidak mungkin bahwa kemampuan siswa untuk memahami bacaan, berpikir kritis, dan berpikir kreatif tidak akan berkembang. Masalah ini terjadi pada anak-anak di SD bukan di jenjang pendidikan tinggi seperti SMA dan Perguruan Tinggi yang semestinya banyak dilatih untuk memiliki kemampuan membaca yang baik, berpikir kritis, dan berpikir kreatif.

\section{Tahap Perancangan \\ Menyiapkan KD dan Perangkat Pembelajaran Pendukung}

Penggunaan LKS sangat besar peranannya dalam proses pembelajaran, sehingga seolah-olah penggunaan LKS dapat menggantikan kedudukan seorang guru. Hal ini dapat dibenarkan, apabila LKS yang digunakan tersebut merupakan LKS yang berkualitas baik. Perancangan LKS Bahasa Indonesia SMP Kelas VII Semester Genap dalam penelitian ini telah mempertimbangkan hal-hal sebagai berikut :

a) Syarat-syarat Didaktik

b) Syarat-syarat Konstruksi

c) Syarat-syarat Teknis

\section{Pemilihan Media Pembelajaran}

Media pembelajaran yang dipilih adalah Lembar Kerja Siswa (LKS) Bahasa Indonesia SMP Kelas VII Semester Genap.

\section{Pemilihan Bentuk Penyajian}

Media pembelajaran ini berbentuk lembaran-lembaran kerja siswa untuk materi satu semester genap kelas VII yang selanjutnya dicetak dan dijilid dalam bentuk buku.

\section{Desain Awal LKS}

Desain awal sebagai pengembangan LKS ini dilakukan dengan mengadaptasi langkah-langkah pengembangan yang ada dari berbagai sumber. LKS Bahasa Indonesia SMP Kelas VII Semester Genap ini disusun dan dikembangkan melalui langkah-langkah sebagai berikut :

a) Menetapkan standar kompetensi, judul, dan tujuan pembelajaran (kompetensi dasar) yang ingin dicapai. Tujuan pembelajaran (kompetensi dasar) merupakan TPU pada Kurikulum 1994, sedangkan indikator merupakan TPK.

b) Menganalisis dan menjabarkan $\mathrm{KD}$ menjadi indikator

c) Menetapkan prosedur, jenis, dan alat penilaian berbasis kelas sesuai dengan misi kurikulum, dalam hal ini adalah Kurikulum Tingkat Satuan Pendidikan.

d) Menetapkan alternatif kegiatan (pengalaman belajar) yang dapat memberikan peluang yang optimal kepada peserta didik untuk mengembangkan keterampilanketerampilan proses di dalam dirinya.

e) Menetapkan dan mengembangkan bahan / media / sumber yang sesuai dengan kemampuan dasar yang akan dicapai, karakteristik peserta didik, fasilitas (sarana dan prasarana), dan karakteristik lingkungan peserta didik.

f) Menyusun LKS Bahasa Indonesia SMP Kelas VII Semester Genap yang lengkap, yaitu menuangkan hasilhasil yang telah dilakukan menjadi sebuah LKS.

Adapun struktur LKS Bahasa Indonesia SMP Kelas VII Semester Genap adalah sebagai berikut :

1. Judul, mata pelajaran, semester, dan tempat

2. Petunjuk belajar

3. Kompetensi yang akan dicapai 
4. Indikator

5. Informasi pendukung

6. Tugas-tugas dan langkah-langkah kerja

7. Penilaian

\section{Kualitas LKS}

Validasi Isi LKS oleh Ahli

Pembelajaran

Berikut ini penjelasan tentang hasil validasi ahli pembelajaran Bahasa Indonesia terhadap LKS. Hasil validasi menunjukkan bahwa jumlah nilai untuk 23 item pernyataan adalah 87 , sehingga rata-rata 3,78 .

Selanjutnya dari jumlah pernyataan yang ada dimasukkan ke dalam rumus nilai untuk mengambil kesimpulan sebagai berikut :

$$
\begin{aligned}
\text { Nilai } & =\frac{\text { Jumlah Skor Validator }}{\text { Jumlah Skor Tertinggi }} \times 100 \% \\
& =\frac{87}{115} \times 100 \% \\
& =0,7565 \times 100 \% \\
& =75,65 \%
\end{aligned}
$$

Nilai validasi sebesar $75,65 \%$ sesuai dengan pendapat Riduwan (2009) menunjukkan hasil yang baik, artinya LKS Bahasa Indonesia kelas VII adalah baik dan layak digunakan sebagai bahan pengajaran model Pembelajaran Berbasis Masalah.

\section{Validasi Bahasa LKS oleh Ahli Bahasa}

Berikut ini penjelasan tentang hasil validasi ahli bahasa terhadap LKS Bahasa Indonesia. Validasi itu menunjukkan bahwa jumlah nilai untuk 5 item pernyataan adalah 21 , sehingga rata-rata 4,2 . Selanjutnya dari jumlah pernyataan yang ada dimasukkan ke dalam rumus nilai untuk mengambil kesimpulan sebagai berikut :

$$
\begin{aligned}
\text { Nilai } & =\frac{\text { Jumlah Skor Validator }}{\text { Jumlah Skor Tertinggi }} \times 100 \% \\
& =\frac{21}{25} \times 100 \% \\
& =0,84 \times 100 \% \\
& =84,00 \%
\end{aligned}
$$

Nilai validasi sebesar $84,00 \%$ sesuai dengan pendapat Riduwan (2009) menunjukkan hasil yang baik, artinya bahasa yang digunakan LKS Bahasa Indonesia kelas VII adalah baik dan layak digunakan sebagai bahan pengajaran model Pembelajaran Berbasis Masalah.

a) Validasi Penyajian dan Kegrafikan

\section{LKS oleh Ahli Grafik}

Berikut ini penjelasan tentang hasil validasi ahli bahasa terhadap LKS Bahasa Indonesia. Hasil validasi ini menunjukkan bahwa jumlah nilai untuk 9 item pernyataan adalah 26 , sehingga ratarata 2,89. Selanjutnya dari jumlah pernyataan yang ada dimasukkan ke dalam rumus nilai untuk mengambil kesimpulan sebagai berikut :

$$
\text { Nilai } \quad \begin{aligned}
= & \frac{\text { Jumlah Skor Validator }}{\text { Jumlah Skor Tertinggi }} \times 100 \% \\
& =\frac{26}{45} \times 100 \% \\
& =0,5778 \times 100 \% \\
& =57,78 \%
\end{aligned}
$$

Nilai validasi sebesar $57,78 \%$ sesuai dengan pendapat Riduwan (2009) menunjukkan hasil yang kurang, artinya penyajian dan kegrafikan yang digunakan LKS Bahasa Indonesia kelas VII adalah kurang baik dan kurang layak digunakan sebagai bahan pengajaran model Pembelajaran Berbasis Masalah.

Revisi LKS sebagai bagian dari Tahap Pengembangan

Penulis memperbaiki LKS sesuai dengan hasil validasi yang telah dilakukan oleh validator ahli. Revisi LKS terdiri dari tiga bagian sebagaimana yang disarankan oleh validator.
b) Perbaikan Isi berdasarkan
Pembelajaran Berbasis Masalah
c) Perbaikan Bahasa
d) Perbaikan Penyajian dan Kegrafikan

\section{Kualitas Penggunaan Uji Coba Terbatas LKS}

Uji coba terbatas LKS ini dilakukan kepada siswa satu kelas berjumlah 32 
anak pada Juni 2013. Uji coba terbatas dilakukan dengan memaksimalkan peranan guru dan siswa. Siswa dikelompokkan menjadi beberapa kelompok dengan model pembelajaran berbasis masalah.

\section{Penggunaan oleh guru}

Tanggapan guru terhadap LKS Bahasa Indonesia yang dikembangkan menunjukkan bahwa jumlah nilai untuk 11 item pernyataan masing-masing guru adalah $37,39,37,37$, sehingga rata-rata untuk empat guru 3,4.

Selanjutnya dari jumlah pernyataan yang ada dimasukkan ke dalam rumus nilai untuk mengambil kesimpulan sebagai berikut :

$$
\begin{aligned}
\text { Nilai } & =\frac{\text { Jumlah Skor Validator }}{\text { Jumlah Skor Tertinggi }} \times 100 \% \\
& =\frac{150}{220} \times 100 \% \\
& =0,6818 \times 100 \% \\
& =68,18 \%
\end{aligned}
$$

Nilai validasi sebesar $68,18 \%$ sesuai dengan pendapat Riduwan (2009) menunjukkan hasil yang cukup, artinya para guru menilai LKS Bahasa Indonesia kelas VII dapat digunakan dengan nilai cukup.

\section{Penggunaan oleh siswa}

Tanggapan observer dan guru terhadap aktivitas siswa ketika pembelajaran menggunakan LKS Bahasa Indonesia Kelas VII Semester Genap menunjukkan bahwa jumlah nilai untuk 12 item pernyataan masing-masing observer dan guru adalah 40, 45, 38, 43, sehingga rata-rata untuk empat guru 3,5.

Selanjutnya dari jumlah pernyataan yang ada dimasukkan ke dalam rumus nilai untuk mengambil kesimpulan sebagai berikut :

$$
\begin{aligned}
\text { Nilai } & =\frac{\text { Jumlah Skor Validator }}{\text { Jumlah Skor Tertinggi }} \times 100 \% \\
& =\frac{166}{240} \times 100 \% \\
& =0,6917 \times 100 \%
\end{aligned}
$$

Nilai validasi sebesar $68,18 \%$ sesuai dengan pendapat Riduwan (2009) menunjukkan hasil yang cukup, artinya para observer dan guru menilai aktivitas anak ketika menggunakan LKS Bahasa Indonesia kelas VII cukup.

\section{Revisi Hasil Uji Coba LKS}

Hasil uji coba terbatas yang telah diuraikan di atas secara umum telah berjalan sesuai kriteria pembelajaran berbasis masalah, sehingga revisi tidak hasil uji coba terbatas tidak diperlukan.

\section{Implementasi Sesungguhnya}

Implementasi sesungguhnya dilakukan kepada siswa sejumlah 95 anak dalam empat ruang kelas. Hasil implementasi menunjukkan bahwa siswa bisa aktif, terlibat langsung dalam pembelajaran serta mampu membangun pembelajaran.

Implementasi LKS agar lebih efektif melalui model pembelajaran berbasis masalah memang peran guru dan siswa harus benar-benar difungsikan sesuai tatacara model pembelajaran berbasis masalah. Hakikat masalah dalam melalui model pembelajaran berbasis masalah adalah kesenjangan antara situasi nyata dan kondisi yang diharapkan. Kesenjangan tersebut bisa dirasakan dari adanya keresahan, keluhan, kerisauan, atau kecemasan. Oleh karena itu, maka materi pelajaran tidak terbatas pada materi pelajaran yang bersumber dari buku saja, tetapi dapat bersumber dari peristiwa-peristiwa tertentu sesuai dengan kurikulum yang berlaku.

\section{Cetak LKS dan Publikasi LKS}

Pencetakan LKS untuk kepentingan publikasi kepada seluruh siswa SMP kelas VII tidak dapat dilakukan tanpa koordinasi dengan pihak-pihak terkait, sehingga penulis dalm hal ini tidak dapat 
melakukan sendiri kegiatan tersebut. Penulis melakukan cetak LKS dan publikasi LKS bersama-sama dengan MGMP Bahasa Indonesia SMP Negeri Kabupaten Gresik.

\section{SIMPULAN}

Berdasarkan hasil penelitian pengembangan yang telah diuraikan pada bab sebelumnya, maka kesimpulan penelitian ini sebagai berikut:

1. Proses pengembangan terdiri dari dua tahap, pertama analisis yang menghasilkan pemahaman oleh penyusun secara utuh tentang LKS, mengumpulkan beberapa LKS yang telah digunakan oleh siswa, pemahaman guru terhadap kebutuhan siswa sehingga menyimpulkan untuk menyusun LKS, draft tentang caracara memahamkan siswa terhadap KD dalam LKS, menyusun LKS menjadi pilihan dan siap untuk ditidaklanjuti. Kedua adalah tahap perancangan antara lain menghasilkan rangkuman materi tia-tiap kompetensi dasar, tersusun rangkuman materi, perlatihan, dan soal-soal dalam uji kompetensi, mencetak LKS dalam lembaran-lembaran, mencetak dalm bentuk buku yang merupakan gabungan dari bab-bab yang telah disusun oleh guru.

2. Kualitas LKS

a. Kualitas produk berdasarkan validasi ahli pembelajaran didapatkan nilai $75,65 \%$ berarti baik, validasi dari ahli bahasa didapatkan nilai $84,00 \%$ berarti baik, dan validari dari ahli grafika dan penyajian didapatkan nilai $57,78 \%$ berarti kurang, diperoleh rata-rata $72,48 \%$ berarti baik.

b. Kualitas penggunaan berdasarkan kuesioner kepada guru dan observasi terhadap siswa. Hasil kuesioner kepada guru didapatkan nilai $75,65 \%$ berarti cukup, dan hasil observasi kepada siswa didapatkan nilai $75,65 \%$ berarti cukup, diperoleh rata-rata $75,65 \%$ berarti baik.

\section{DAFTAR PUSTAKA}

Abdorrakhman Ginting, Esensi Praktis Belajar dan Pembelajaran (Bandung: Humaniora, 2008).

Abdul Majid,Perencanaan Pembelajaran Mengem-bangkan Standar Kompetensi Guru (Bandung: PT Remaja Rosdakarya, 2007).

Asnawir dan Basyiruddin Usman, Media Pembelajaran (Ciputat Pers: Jakarta, 2002).

Azhar Arsyad, Media Pembelajaran (Jakarta: PT. Raja Grafindo Persada, 2005).

Darliana. 1991. Metode Pembelajaran Ketrampilan Proses. Jakarta: Depdikbud.

Dhari, HM. dan Dharyono, AP. 1988. Perangkat Pembelajaran. Malang: Depdikbud. 